\title{
Evaluasi Penerimaan Aplikasi Mobile Banking BNI Terhadap Minat Nasabah Menggunakan UTAUT (Studi Kasus:BNI Cabang UGM)
}

\author{
Mohammad Santosa Mulyo Diningrat ${ }^{1)}$, Bambang Soedjiono W.A ${ }^{2)}$, Henderi ${ }^{3)}$ \\ 1, 2, 3,Program Pascasarjana Magister Teknik Informatika Universitas Amikom Yogyakarta \\ Jl. Ring Road Utara Condong Catur, Sleman, Yogyakarta, Indonesia \\ Email: ${ }^{1}$ msantosamd@gmail.com, ${ }^{2}$ bambang.s@amikom.ac.id, ${ }^{3}$ henderi@amikom.ac.id
}

\begin{abstract}
Abstrak
Teknologi Informasi merupakan aset penting bagi suatu organisasi. Penggunaan teknologi informasi digunakan untuk mempermudah kinerja organisasi menjadi lebih efisien dan efektif. Perbankan memberikan kebebasan dengan memberikan kemudahan nasabah dalam bertransaksi. Layanan yang disediakan menyesuaikan mobilitas konsumen. Guna memenuhi harapan konsumen, perbankan melakukan inovasi dengan mengikuti perkembangan teknologi informasi dan memberikan kemudahan kepada konsumen dalam melakukan transaksi, diantaranya dengan fitur ATM, SMS banking, internet banking, phone banking dan mobile banking. Mobile banking merupakan inovasi dengan memberikan kemudahan kepada nasabah tanpa harus datang ke kantor cabang untuk melakukan transaksi dan mengurangi antrian dalam bertransaksi. Nasabah dapat melakukan transaksi dimana dan kapan saja tanpa batas waktu. Evaluasi sistem informasi merupakan aspek penting dalam menilai keberhasilan implementasi sistem informasi. Tujuan utama evaluasi penerimaan Aplikasi Mobile Banking BNI terhadap minat Nasabah menggunakan UTAUT yaitu untuk menguji adanya pengaruh performance expectancy, effort expextancy, social influence dan facilitating condition terhadap minat nasabah menggunaan mobile banking pada nasabah BNI cabang UGM di Yogyakarta.
\end{abstract}

Kata kunci:Evaluasi Penerimaan, Aplikasi, Mobile Banking, Bank BNI, UTAUT

\section{PENDAhuluan}

Pengelolaan teknologi informasi yang mencukupi dalam suatu organisasi merupakan sebuah keuntungan dari adanya teknologi informasi (Ernawati dan Santoso, 2016). Perkembangan zaman yang didukung dengan perkembangan teknologi, menyebabkan kebutuhan manusia terhadap informasi semakin kompleks, sehingga perusahaan harus memperhatikan kemajuan teknologi informasi dan lebih mengoptimalkan fasilitas teknologi informasi dalam rangka dapat bertahan dan menang dalam persaingan usaha di pasar global.

Aplikasi Perbankan yang menjadi perhatian adalah mobile banking atau biasa disebut $m$-banking yang merupakan layanan perbankan untuk mendukung kelancaran dan kemudahan kegiatan perbankan serta keefektifan dan keefisienan nasabah untuk melakukan berbagai transaksi. Mobile banking merupakan inovasi dengan memberikan kemudahan kepada nasabah tanpa harus datang ke kantor cabang untuk melakukan transaksi dan mengurangi antrian dalam bertransaksi. Nasabah dapat melakukan transaksi dimana dan kapan saja tanpa batas waktu.

BNI Mobile Banking adalah fasilitas layanan perbankan yang memudahkan nasabah bertransaksi langsung melalui smartphone secara aman, mudah dan cepat. Keunggulan dari m-banking mengenai pengelolaan dan manajemen resiko penyelenggaraan kegiatan internet banking (termasuk pada mobile banking) berdasarkan peraturan Bank Indonesia No.5/8/PBI/2003 tentang penerapan manajemen resiko pada aktifitas pelayana jasa bank melalui sistem internet. Penawaran layanan perbankan melalui mobile banking banyak dilakukan media elektronik, namun belum banyak nasabah yang menggunakan mobile banking dalam melakukan transaksi keuangan.

Evaluasi sistem informasi merupakan aspek penting dalam menilai keberhasilan 
implementasi sistem informasi. Tujuan utama evaluasi untuk menilai tingkat aksebilitas dari fungsi sistem, menilai pengalaman interaksi pengguna dengan sistem serta mengidentifikasi masalah yang terjadi pada sistem.

Menurut Amanullah dan Sutopo (2014) persepsi manfaat, kemudahan penggunaan dan kepercayaan yang diteliti terbukti secara positif dan signifikan mempengaruhi variabel dependen yaitu sikap positif penggunaan layanan mobile banking. Susanti, dkk (2015) memaparkan bahwa hasil uji $\mathrm{F}$ pada persepsi kegunaan, persepsi resiko dan persepsi kepercayaan memiliki pengaruh yang simultan terhadap minat penggunaan mobile banking.

Selanjutnya penelitian Mubiyantoro (2012) menunjukan bahwa konstruk persepsi kemudahan penggunaan dan presepsi kesesuaian berpengaruh terhadap sikap untuk menggunakan layanan mobile banking. Sebaliknya, konstruk persepsi kegunaan dan persepsi resiko tidak berpengaruh terhadap sikap digunakannya layanan mobile banking.

Penelitian Tirtana dan Sari (2014) menyatakan penggunaan mobile banking akan meningkatkan produktivitas dan kinerja nasabah apabila nasabah memiliki tingkat kepercayaan yang tinggi terhadap aplikasi mobile banking, nasabah percaya bahwa mereka dapat mengembangkan kinerja, meningkatkan produktivitas dan meningkatkan efektivitas ketika menggunakan mobile banking.

Penerapan metode TAM dalam pengujian penerimaan sistem informasi yang dilakukan Sayekti dan Putarta (2016) dalam model penerimaan sistem informasi keuangan daerah untuk mengetahui apakah dari sisi user penggunaan sistem dapat diterima sebagai suatu sistem yang meningkatkan kinerja, bukan hanya sekedar kewajiban yang harus dijalani. kekhawatiran terhadap akses dalam melakukan transaksi keuangan secara online, terutama membutuhkan perlindungan terhadap akses informasi, sehingga keamanan dalam akses tersebut harus diperhatikan. Namun, terdapat pengembangan dari metode TAM, yaitu dengan pendekatan metode UTAUT yang dikemukanan oleh Venkatesh, dkk pada 2003. Sama seperti penelitian yang dilakukan Annas pada 2015 yang memaparkan bahwa penerimaan user teknologi mobile banking dapat dilakukan dengan UTAUT yang menghasilkan kesimpulan bahwa masing-masing variabel dapat mempengaruhi niat keperilakuan di kalangan pengguna mobile banking.

Penelitian ini akan memfokuskan pada pemanfaatan UTAUT sebagai kerangka teoritis untuk mengetahui pengaruh faktor atau konstruksi UTAUT terhadap penerimaan BNI mobile banking khususnya BNI kantor cabang Universitas Gajah Mada Yogyakarta.

\section{METODE PENELITIAN}

Beberapa tahapan dalam penelitian dapat dilihat pada Gambar 1 di bawah ini.

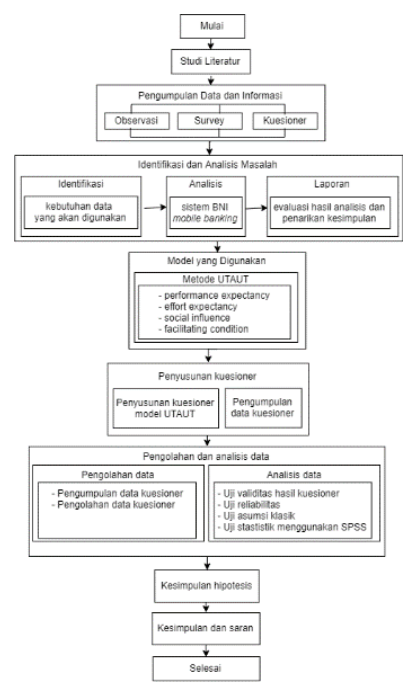

Gambar 1. Alur Penelitian

Gambar di atas merupakan langkah-langkah tahapan alur penelitian yang akan digunakan dalam penelitian ini meliputi:

1. Studi literatur

Mengetahui berbagai penelitian terdahulu yang mempunyai kaitan dengan penelitian yang dilakukan. Identifikasi masalah, merumuskan latar belakang masalah, rumusan masalah, batasan masalah, tujan penelitian, dan manfaat penelitian.

2. Pengumpulan data dan informasi

Penyusunan menggunakan model UTAUT yang terdiri dari. Survey berupa pengisian kuesioner dan wawancara secara langsung dengan nasabah BNI yang menggunakan BNI mobile banking.

3. Identifikasi dan analisis data

Setelah data terkumpul dilakukan uji validitas dan reabilitas untuk mengetahui tingkat keandalan dan kesahihan alat ukur yang digunakan. Menunjukkan sejauh mana 
pengukuran dapat memberikan hasil relatif pada kuesioner dan wawancara.

4. Pengolahan dan Analisis Data

Uji statistik menggunakan software SPSS, asumsi berupa uji normalitas, uji multikolinearitas dan uji heteroskedasitas.

5. Pengujian Hipotesis

Melakukan pengujian instrument hipotesis dengan pengolahan data SPSS dan menyimpulkan hasil pengujian terhadap analisis data yang telah dilakukan.

6. Kesimpulan dan saran

Didapatkan dari penelitian yang telah dilakukan. Penyusunan laporan merupaka tahapan terakhir untuk hasil dari keseluruhan penelitian.

\section{TINJAUAN PUSTAKA}

Ada beberapa penelitian yang pernah dilakukan salah satunya oleh Penelitian Wardani, dkk (2018) yang meneliti tentang analisis minat pengguna layanan BNI internet banking dengan menggunakan model UTAUT pada hasil penelitian menunjukkan variabel behavioral intention memiliki hubungan positif terhadap variabel performance expectancy dan variabel social influence tetapi memiliki hubungan negatif terhadap variabel effort expectancy, Berbeda dengan ekspektasi peneliti, sehingga dalam penelitian yang akan dilakukan perlunya hipotesis sebagai asumsi dugaan yang harus dibuktikan kebenarannya.

Serta ada juga Soebali (2017) dalam penelitiannya yang bertujuan untuk menganalisis faktor yang mempengaruhi penerimaan dan penggunaan aplikasi gojek menggunakan UTAUT dengan telah dihilangkan variabel behavior intention dan moderator. Dilakukan pengujian terhadap 50 sampel, performance expectancy, effort expectancy, social influence dan facilitating conditions secara berkelanjutan berpengaruh positif dan signifikan terhadap use behavior. Sementara secara terpisah hanya performance expectancy dan social influence yang memiliki pengaruh positif dan signifikan terhadap use behavior. Sedangkan effort expectancy dan facilitating conditition tidak memiliki pengaruh yang posistif dan signifikan terhadap use behavior pada aplikasi gojek.

\section{HASIL DAN PEMBAHASAN \\ a. Gambaran Umum Objek Penelitian}

Jenis penelitian ini adalah penelitian kuantitatif dengan menguji hipotesis. Metode pengumpulan data menggunakan metode survey dengan kuesioner dalam pengumpulan data. Objek dalam penelitian ini adalah seluruh nasabah pada Bank BNI cabang UGM di Yogyakarta.

Metode pengambilan sampel dengan metode convinience sampling yaitu teknik pengambilan sampel secara bebas. Jumlah kuesioner yang diperoleh dan dapat diolah sebanyak 134 kuesioner. Proses pengambilan sampel berdasarkan responden pada Bank BNI cabang UGM di Yogyakarta ditunjukkan pada tabel 1 dibawah ini :

Tabel 1. Jumlah Kuisioner

\begin{tabular}{|c|c|}
\hline Kriteria & Jumlah \\
\hline Kuesioner yang disebar & 134 \\
\hline Kuesioner yang kembali & 134 \\
\hline $\begin{array}{l}\text { Respon rate }=134 / 134 \\
\mathrm{x} 100 \%\end{array}$ & $100 \%$ \\
\hline Data yang diperoleh & 134 \\
\hline $\begin{array}{l}\text { Data yang tidak dapat } \\
\text { diolah }\end{array}$ & 0 \\
\hline $\begin{array}{l}\text { Jumlah Kuesioner Siap } \\
\text { Dianalisis }\end{array}$ & 134 \\
\hline $\begin{array}{l}\text { Usable respon rate }=134 \\
/ 134 \times 100 \%\end{array}$ & $100 \%$ \\
\hline
\end{tabular}

Dari data yang diperoleh dengan menggunakan kuesioner yang diberikan secara langsung kepada responden. Berdasarkan tabel 4.1 diketahui bahwa kuesioner yang disebar peneliti sebanyak 134 kuesioner kepada responden, kuesioner yang kembali sebanyak 134 kuesioner. Total sampel yang digunakan dalam penelitian ini sebanyak 134 kuesioner.

\section{b. Uji Validitas}

Uji validitas digunakan untuk melihat sejauh mana suatu alat pengukur itu bisa mengukur apa yang ingin diukur. Guna melihat valid atau tidaknya sebuah data maka kolom yang dilihat adalah kolom pearson correlation. Dikatakan valid jika $\mathrm{r}_{\text {hitung }}>$ 0,1697 . Untuk melihat tingkat validitas semua item pernyataan kuesioner yang penulis susun, dapat dilihat pada tabel 2 di bawah ini. 
Tabel 2. Hasil Uji Validitas Variabel

\begin{tabular}{|l|l|l|l|l|}
\hline $\begin{array}{l}\mathbf{N} \\
\mathbf{o}\end{array}$ & $\begin{array}{l}\text { Indikat } \\
\text { or }\end{array}$ & $\begin{array}{l}\mathbf{r} \\
\text { hitun } \\
\text { g }\end{array}$ & $\begin{array}{l}\text { simpula } \\
\mathbf{n}\end{array}$ & $\begin{array}{l}\text { Keterang } \\
\text { an }\end{array}$ \\
\hline 1 & PE_1 & 0,853 & Valid & $\begin{array}{l}\text { Karena r } \\
\text { hitung } \\
0,1697\end{array}$ \\
\hline 2 & PE_2 & 0,875 & Valid & $\begin{array}{l}\text { Karena r r } \\
\text { hitung } \\
0,1697\end{array}$ \\
\hline 3 & PE_3 & 0,874 & Valid & $\begin{array}{l}\text { Karena r } \\
\text { hitung } \\
0,1697\end{array}$ \\
\hline
\end{tabular}

Data di atas menunjukkan bahwa semua nilai $r$ hitung lebih besar dibandingkan nilai $r$ tabel sehingga dapat dikatakan bahwa semua item pertanyaan tentang variabel Performance expectancy tersebut valid dan dapat digunakan untuk uji-uji selanjutnya.

\section{c. Uji Realibilitas}

Uji reliabilitas bertujuan untuk melihat sejauh mana suatu alat ukur dapat dipercaya atau diandalkan bila digunakan berkali-kali untuk mengukur gejala yang sama. Dikatakan reliabel atau handal jika jawaban seseorang atas pertanyaan yang disampaikan konsisten dari waktu ke waktu. Dikatakan handal atau reliabel jika memiliki koefisien keandalan atau cronbach's alpha sebesar 0,7 atau lebih. Di bawah ini merupakan daftar cronbach alpha untuk variabel penelitian yang ada atas dasar perhitungan dengan menggunakan SPSS yang bisa dilihat di tabel 3 dibawah ini.

Tabel 3. Hasil Uji Realibilitas

\begin{tabular}{|l|l|l|l|l|}
\hline No & Variabel & $\begin{array}{l}\text { Cronbac } \\
\mathrm{h} \alpha\end{array}$ & $\begin{array}{l}\text { Simpul } \\
\text { an }\end{array}$ & Keteraangan \\
\hline $\begin{array}{l}\text { Performa } \\
\text { nce } \\
\text { expectanc } \\
y\end{array}$ & 0,832 & $\begin{array}{l}\text { Reliabe } \\
1\end{array}$ & $\begin{array}{l}\text { Karena } \\
\text { Cronbach }>0,7\end{array}$ \\
\hline $\begin{array}{l}\text { Effort } \\
\text { expextanc } \\
y\end{array}$ & 0,711 & $\begin{array}{l}\text { Reliabe } \\
1\end{array}$ & $\begin{array}{l}\text { Karena } \\
\text { Cronbach }>0,7\end{array}$ \\
\hline 3 & $\begin{array}{l}\text { Social } \\
\text { influence }\end{array}$ & 0,868 & 1 & $\begin{array}{l}\text { Reliabe } \\
\text { Carena } \\
\text { Cronbach }>0,7\end{array}$ \\
\hline $\begin{array}{l}\text { Facilitatin } \\
g\end{array}$ & & Reliabe & $\begin{array}{l}\text { Karena } \\
\text { Cronbach }>0,7\end{array}$ \\
\hline
\end{tabular}

\begin{tabular}{|l|l|l|l|l|}
\hline 5 & $\begin{array}{l}\text { Behavior } \\
\text { intention }\end{array}$ & 0,826 & $\begin{array}{l}\text { Reliabe } \\
1\end{array}$ & $\begin{array}{l}\text { Karena } \\
\text { Cronbach }>0,7\end{array}$ \\
\hline 6 & $\begin{array}{l}\text { Use } \\
\text { behavior }\end{array}$ & 0,814 & $\begin{array}{l}\text { Reliabe } \\
1\end{array}$ & $\begin{array}{l}\text { Karena } \\
\text { Cronbach }>0,7\end{array}$ \\
\hline
\end{tabular}

Data di atas menunjukkan bahwa semua nilai Cronbach Alpha yang tertera dalam Tabel Reability Statistics (terlampir) hasil perhitungan dengan menggunakan SPSS untuk variabel aktifitas fisik lebih besar dari 0,7 sehingga dapat dikatakan bahwa instrumen penelitian ini handal (reliabel) dan dapat digunakan untuk uji selanjutnya.

Setelah semua data dinyatakan layak untuk dilakukan uji selanjutnya, maka langkah terakhir yang dilakukan adalah melakukan uji hipotesis. Uji ini bertujuan untuk menjawab rumusan masalah sekaligus dugaan sementara atas jawaban rumusan masalah tersebut yang tertuang dalam hipotesis. Beberapa hal yang termasuk ke dalam uji hipotesis ini antara lain persamaan regresi, uji $F$ (uji simultan), koefisien determinasi $\left(\mathrm{R}^{2}\right)$ dan uji t (uji parsial).

\section{d. Persamaan Regresi Linier Berganda}

Hasil perhitungan dan pengolahan data dengan menggunakan Statistical Program for Social Science (SPSS), didapatkan tabel coefficients dibawah ini. Dari tabel 4.23 dapat diambil beberapa kesimpulan, salah satunya adalah persamaan regresi linier berganda.

Tabel 4. Hasil Uji Regregi Berganda Coefficients $^{\mathrm{a}}$

\begin{tabular}{|c|c|c|c|c|c|c|}
\hline & & & Coefficier & its $\mathrm{s}^{\mathrm{a}}$ & & \\
\hline & Model & $\begin{array}{r}\text { Unst } \\
\text { Co }\end{array}$ & $\begin{array}{l}\text { ndardized } \\
\text { fficients }\end{array}$ & $\begin{array}{l}\text { Standardized } \\
\text { Coefficients }\end{array}$ & $t$ & Sig. \\
\hline & & $\mathrm{B}$ & Std. Error & Beta & & \\
\hline$\overline{1}$ & (Constant) & 3.416 & 1.091 & & 3.132 & .002 \\
\hline & $\mathrm{PE}$ & .873 & .067 & .743 & 13.104 & .000 \\
\hline & $\overline{\mathrm{EE}}$ & -.238 & .097 & -.139 & -2.453 & .015 \\
\hline & SI & .025 & .051 & .028 & .486 & .628 \\
\hline
\end{tabular}

Melihat nilai Unstandardizet Coefficients Beta di atas, maka dapat ditentukan persamaan regresi linier berganda yang dihasilkan darienelitian ini, sebagai berikut: $\mathrm{Y}=3,416$ $+0,873 \mathrm{X}_{1}-0,238 \mathrm{X}_{2}+0,025 \mathrm{X}_{3}$

Yang berarti bahwa:

a. Konstanta sebesar 3,416 yang berarti jika variabel Performance expectancy, Effort expextancy, dan Social influence dianggap nol maka variabel 
Behavior intention hanya sebesar 3,416 .

b. Koefisien regresi variabel Performance expectancy diperoleh nilai sebesar 0,873 yang berarti jika variabel Performance expectancy mengalami kenaikan sementara variabel Effort expextancy, dan Social influence diasumsikan tetap maka variabel Behavior intention juga akan mengalami kenaikan sebesar 0,873 .

c. Koefisien regresi variabel Effort expextancy diperoleh nilai sebesar 0,238 yang berarti jika variabel Effort expextancy mengalami kenaikan sementara variabel Performance expectancy dan Social influence diasumsikan tetap maka variabel Behavior intention akan mengalami penurunan sebesar 0,238.

d. Koefisien regresi variabel Social influence diperoleh nilai sebesar 0,025 yang berarti jika variabel Social influence mengalami kenaikan sementara variabel Performance expectancy dan Effort expextancy diasumsikan tetap maka variabel Behavior intention juga akan mengalami kenaikan sebesar 0,246.

\section{KESIMPULAN DAN SARAN}

\section{a. Kesimpulan}

Berdasarkan hasil pembahasan dan analisis yang telah dilakukan, dapat diambil kesimpulan bahwa:

1. BNI mobile banking sudah memenuhi kebutuhan, dilihat dari harapan usaha dan harapan kinerja. Namun, pengaruh sosial kurang berpengaruh karena rekening bersifat individu dan jarang ada orang dengan rekening yang sama dalam komunitas tertentu.

2. Banyak dari nasabah mengeluhkan tampilan aplikasi yang membingungkan, nasabah masih kebingungan menggunakan aplikasi, sehingga memperlukan waktu yang lebih untuk menggunakan BNI mobile banking.

\section{b. Saran}

Berdasarkan penelitian yang telah dilakukan, maka saran yang dapat diberikan penulis untuk penelitian selanjutnya sebagai berikut :
1. Pada penelitian yang telah dilakukan terdapat variabel yang belum terpenuhi sehingga pada penelitian selanjutnya dapat menindaklanjuti variabel tersebut sehingga implementasinya dapat optimal.

2. Pada penelitian selanjutnya harus lebih diperjelas butir-butir pertanyaan

\section{REFERENSI}

Ghazali, M. R., \& Hidayati, R., 2011, Analisis Pengaruh Lokasi, Promosidan Kualitas Layanan Terhadap Keputusan Membeli (Warnet (Warung Internet) XYZ Jl. Singosari, Kota Semarang) (Doctoral dissertation, Universitas Diponegoro

Ghozali, I., 2011, Analisis Multivariate Program IBM SPSS 19. Semarang: Badan Penerbit Universitas Diponogoro

Soebali, L. F., \& Mahendra, I., 2017, Analisa Faktor-faktor Yang Mempengaruhi Penerimaan Dan Penggunaan Aplikasi Go-jek Menggunakan Unified Theory of Acceptance and Use of Technology (UTAUT). Jurnal Pilar Nusa Mandiri

Sugiyono, Prof., Dr., 2012, Metode Penelitian Kuantitatif Kualitatif dan R\&D. Alfabeta, $\mathrm{CV}$, Bandung

Venkatesh, Viswanath, Michael G. Morris, Girdon B. Davis, Fred D Davis., 2003, User Acceptance of Information Technology : Toward A unified view 1, MIS Quraterly 